\title{
Soft tissue injuries associated with traumatic locked facets in the cervical spine
}

\author{
AC Moraes, A Serdeira, A Pereira Filho, E Zardo and J Deitos \\ Department of Neurosurgery, Municipal Emergency Hospital, Trauma Center Level 1 Porto Alegre, Brazil
}

The clinical, radiological and operative findings in 10 consecutive patients with cervical spine trauma presenting with locked facets (bilaterally in nine patients) are reported. The treatment was cervical traction until reduction of the locked facets was achieved, followed by anterior surgical decompression and ostheosynthesis. Intervertebral disc herniation was present in nine of the patients, and ruptured calcified posterior longitudinal ligament was present in the remaining patient. Four patients improved after treatment (none of these had clinically complete tetraplegia preoperatively), and three patients died. Associated soft tissue injuries producing spinal cord compression after reduction of cervical locked facets were verified in all of the patients of this series, suggesting that systematic surgical exploration should be done in this category of patients.

Keywords: cervical spine; intervertebral disc; spinal trauma; locked facets

\section{Introduction}

Traumatic facet luxation of the cervical spine was reported to be associated with medullary or nerve root compression by a ruptured intervertebral disc, bone fragments or a hematoma with varying incidence in the literature ${ }^{1-7}$ from $5 \%$ to $60 \%$. The incidence is even higher $(80 \%)$ if we consider only the patients with bilateral locked facets. ${ }^{7}$ It is conceivable that such a wide range of incidence is in part due to difficulties in the radiological diagnosis of these lesions, ${ }^{8,9}$ as well as to diverse diagnostic and management routines.

This report concerns our recent experience with 10 consecutive patients with traumatic cervical locked facets. All the patients presented associated soft tissue injuries producing spinal cord compression after skull traction and radiological realignment of the cervical spine.

\section{Patients, methods and results}

Sixty-five patients with acute cervical spine trauma were admitted to the Municipal Emergency Hospital of Porto Alegre (Brazil) between January and December 1993. Ten of these patients $(15 \%)$ had locked facets. The injuries resulted from car accidents in nine patients, and a fall accident in one patient. The criteria for neurological involvement ${ }^{10}$ are presented in Table 1. The clinical data are summarized in Table 2.

All patients were examined with plain radiographs and computed tomography $(\mathrm{CT})$ of the cervical spine

Correspondence: AC Moraes, Rua Pedro Ivo 744, ap. 401, BR-90450-210 Porto Alegre, RS, Brazil
Table 1 Neurological status after spinal injury (Frankel et al $^{10}$ )

A Complete deficit below the level of lesion
B Sensibility present below the level of lesion
C Motoricity present below the level of lesion, grade 2
or less power in the majority of muscle groups
D Motoricity present below the level of lesion, grade 3
or more power in the majority of muscle groups
No neurological impairment

on admission. The patients admitted up to $8 \mathrm{~h}$ after injury were treated with methylprednisolone. ${ }^{11}$

The initial treatment was by skull traction until radiological reduction of the locked facets was achieved. None of the patients presented clinical worsening due to skull traction. Three patients were further examined with magnetic resonance tomography (MR), and two with myelography and CT.

All patients were operated on between $8 \mathrm{~h}$ and 24 days after anatomical realignment. In six patients a radiological diagnosis of spinal cord compression by an intervertebral disc herniation or an epidural hematoma at the site of injury was diagnosed preoperatively (in three patients examined with MR, in two with myelo-CT, and in a patient with an epidural hematoma, which also had a disc herniation verified during the operation). The remaining four patients were operated on to stabilize the cervical spine. Anterior decompression and osteosynthesis was carried out in all patients, and five patients were also submitted to a posterior arthodesis. During surgery, soft tissue injuries producing spinal cord compression were verified in all of 
Table 2 Clinical data of the patients

\begin{tabular}{|c|c|c|c|c|c|c|c|c|c|c|}
\hline \multirow[t]{2}{*}{ Case } & \multirow[t]{2}{*}{ Age } & \multirow[t]{2}{*}{ Sex } & \multirow{2}{*}{$\begin{array}{l}\text { Skeletal } \\
\text { injury }\end{array}$} & \multirow{2}{*}{$\begin{array}{l}\text { Means of } \\
\text { diagnosis }\end{array}$} & \multicolumn{2}{|c|}{ Interval } & \multirow{2}{*}{$\begin{array}{l}\text { Associated } \\
\text { injury }\end{array}$} & \multirow[t]{2}{*}{ Surgery } & \multirow{2}{*}{\multicolumn{2}{|c|}{$\begin{array}{l}\text { Outcome } \\
\text { (>3 months) } \\
\text { Frankel } \\
\text { initial/final }\end{array}$}} \\
\hline & & & & & $\begin{array}{l}\text { Trauma } \\
\text { alignment }\end{array}$ & $\begin{array}{l}\text { Alignment } \\
\text { surgery }\end{array}$ & & & & \\
\hline 1 & 27 & $\mathrm{M}$ & BFS C4/C5 & CT & $>8 \mathrm{~h}$ & 11 & HNP & DAA & A & Death \\
\hline 2 & 28 & $\mathrm{~F}$ & $\begin{array}{l}\text { BFS, F. lamina } \\
\text { C6/C7 }\end{array}$ & CT & $<8 \mathrm{~h}$ & 3 & HNP & $\mathrm{DAA}$ & A & Death \\
\hline 3 & 34 & $\mathrm{M}$ & $\begin{array}{l}\text { BFS, F lateral mass } \\
\mathrm{C} 6 / \mathrm{C} 7\end{array}$ & CT + myclo & $>8 \mathrm{~h}$ & 24 & HNP & $\mathrm{DAA}+\mathrm{graft}+\mathrm{AP}$ & $\mathrm{B}$ & B \\
\hline 4 & 24 & $\mathrm{~F}$ & $\begin{array}{l}\text { BFS, F. lamina } \\
\text { C5/C6 }\end{array}$ & $\begin{array}{l}\mathrm{CT}+\mathrm{EMG}+ \\
\text { myelo }\end{array}$ & $<8 \mathrm{~h}$ & 21 & HNP & $\mathrm{DAA}+$ graft $+\mathrm{AP}$ & $\mathrm{B}$ & $\mathrm{E}$ \\
\hline 5 & 34 & $\mathrm{M}$ & $\begin{array}{l}\text { UFS, F. pedicle } \\
\text { C6/C7 }\end{array}$ & $\mathrm{CT}$ & $<8 \mathrm{~h}$ & 5 & HNP & DAA & $\mathrm{B}$ & $\mathrm{D}$ \\
\hline 6 & 40 & $\mathrm{M}$ & BFS C4/C5 & $\mathrm{CT}+\mathrm{MRI}$ & $>8 \mathrm{~h}$ & 10 & $\begin{array}{l}\mathrm{HNP}+\text { bone } \\
\text { fragment }\end{array}$ & $\begin{array}{l}\mathrm{DAA}+\mathrm{AP}+ \\
\text { instrumentation }\end{array}$ & $\mathrm{B}$ & $\mathrm{D}$ \\
\hline 7 & 34 & $\mathrm{M}$ & BFS C6/C7 & $\mathrm{CT}+\mathrm{MRI}$ & $>8 \mathrm{~h}$ & 10 & $\begin{array}{l}\mathrm{HNP}+\text { bone } \\
\text { fragment }\end{array}$ & $\mathrm{DAA}+\mathrm{AP}$ & $\mathrm{D}$ & $\mathrm{E}$ \\
\hline 8 & 65 & $\mathrm{~F}$ & $\begin{array}{l}\text { BFS, F. lamina } \\
\text { C6/C7 }\end{array}$ & $\mathrm{CT}+\mathrm{MRI}$ & $<8 \mathrm{~h}$ & 4 & $\begin{array}{l}\mathrm{HNP}+\mathrm{PPL} \\
\text { calcif. }\end{array}$ & DAA & A & Death \\
\hline 9 & 26 & $\mathrm{M}$ & $\begin{array}{l}\text { BFS, F. lamina } \\
\text { C4/C5 }\end{array}$ & CT & $<8 \mathrm{~h}$ & 1 & HNP & $\begin{array}{l}\text { DAA + corpectomy } \\
+ \text { graft }\end{array}$ & A & A \\
\hline 10 & 47 & M & $\begin{array}{l}\text { BFS, F. lamina } \\
\text { C6/C7 }\end{array}$ & CT & $<8 \mathrm{~h}$ & 2 & $\begin{array}{l}\text { HNP + epid } \\
\text { hematoma }\end{array}$ & $\mathrm{DAA}+\mathrm{AP}$ & A & A \\
\hline
\end{tabular}

$\mathrm{DAA}=$ Discectomy anterior approach; $\mathrm{AP}=$ Artrodesis posterior; $\mathrm{PLL}=$ Posterior longitudinal ligament $\mathrm{HNP}=\mathrm{Herniated}$ nucleous pulposus; $\mathrm{BFS}=\mathrm{Bilateral}$ facet subluxation; UFS $=$ Unilateral facet subluxation; FX $=$ Fracture 
the patients. Intervertebral disc herniations were present in nine patients (in two associated with displaced bone fragments, and in another patient associated with an epidural hematoma), and the posterior longitudinal ligament was calcified and ruptured in the remaining patient.

Three patients died within 3 months of the trauma. All of them had complete tetraplegia and impaired respiratory function. Two patients died of respiratory complications and one patient because of hemodynamic instability. The remaining patients were examined between 8 and 24 months after trauma. Four patients improved after treatment (none of these had clinically complete tetraplegia preoperatively.

\section{Discussion}

Although our series is too small for statistical analysis, our results with patients presenting neurological improvement $(40 \%)$ are comparable with those reported in the literature. ${ }^{4,6}$ The patients who died were clinically stable at the time of surgery, but it can be discussed whether they might have been submitted to less invasive treatment because they were severely disabled.

Our most important finding was that associated soft tissue injuries producing spinal cord compression after reduction of cervical locked facets were verified in all of the patients of this series. This observation endorses the use of systematic surgical exploration in this category of patients.

\section{References}

1 Flanders AE et al. Acute cervical spine trauma correlation of MR imaging findings with degree of neurological deficit. Radiology 1990; 177: 25-33.

2 Barros-Filho TEP et al. Hérnia discal traumática da coluna cervical. Rev Hosp Clin Fac Med São Paulo 1991; 46: 276-279.

3 Davis JS et al. Cervical spine hyperextension injuries: MR findings. Radiology 1991; 180: 245-251.

4 Harringtton JF, Matt JL, Smith AS. Disc herniation in cervical fracture subluxation. Neurosurgery 1991; 29: 274-279.

5 Olerud C, Jónsson H Jr. Compression of the cervical spinal cord after reduction of fracture-dislocations. Acta Orthop Scand 1991; 62: 599-601.

6 Rizzolo SJ et al. Intervertebral disc injury complicating cervical spine trauma. Spine 1991; 16(Suppl 6): S187-189.

7 Doran SE, Papadopoulos SM, Ducker TB, Lillehel KO. Magnetic resonance imaging documentation of coexistent traumatic locked facets of the cervical spine and disc herniation. J Neurosurg 1993; 79: 341-345.

8 Pech P, Kilgore DP, Pojunas KW, Haughton VM. Cervical spinal fractures: CT detection. Radiology 1985; 157: 117-120.

9 Jónsson H Jr, Bring G, Rauschning W, Sahlstedt B. Hidden cervical spine injuries in traffic accident victims with skull fractures. J Spinal Disord 1991; 4: 251-263.

10 Frankel HL et al. The value of postural reduction in the initial management of closed injuries of the spine with paraplegia and tetraplegia. Paraplegia 1969; 7: 179-192.

11 Bracken MB et al. Methylprednisolone or naloxone treatment after acute spinal injury: 1-year follow-up data results of the second Netional Acute Spinal Cord Injury Study. J Neurosurg 1992; 76: 23-31. 